\title{
Changes in mountain vascular plants of the 'Jar rzeki Raduni’ nature reserve (Poland) within the last 50 years
}

\author{
Wojciech Zarzycki ${ }^{1}$, Magdalena Zarzycka ${ }^{1}$, Joanna Gołębiewska ${ }^{2 *}$ \\ \& Marek Podsiedlik ${ }^{3}$
}

\begin{abstract}
${ }^{1}$ Department of Ecology, Faculty of Biology and Environmental Protection, University of Silesia in Katowice, Jagiellońska 28, 40-032 Katowice, Poland

${ }^{2}$ Department of Plant Taxonomy and Nature Conservation, Faculty of Biology, University of Gdańsk, Wita Stwosza 59, 80-308 Gdańsk, Poland ${ }^{3}$ Department of Botany, Faculty of Horticulture and Landscape Architecture, Poznań University of Life Sciences, Wojska Polskiego 71C, 60-625 Poznań, Poland

* corresponding address (e-mail: j.golebiewska@biol.ug.edu.pl)
\end{abstract}

\begin{abstract}
Jar rzeki Raduni' is a landscape nature reserve created in 1972, which covers an area of 74,26 ha. The reserve protects the Radunia river gorge in the moraine upland of the Kashubian Lake District. In past, the reserve was an object of numerous botanical studies, and it was distinguished by a large share of mountain species. The main aim of this research was to define the current state of mountain species of the studied area compared to historical data. The study was carried out in 2017 . Eight mountain species were noted: Aconitum variegatum, Alnus incana, Bupleurum longifolium, Chaerophyllum hirsutum, Dryopteris expansa, Huperzia selago, Pleurospermum austriacum and Ribes alpinum. The occurrence of five species was not confirmed: Coeloglossum viride, Epipogium aphyllum, Melampyrum sylvaticum, Polygonatum verticillatum and Valeriana sambucifolia.
\end{abstract}

Key words: mountain species in lowlands, Gdańsk Pomerania, Baltic region

\section{Introduction}

There are numerous publications referring to the topic of occurrence of mountain flora in lowlands (Jakubowska-Gabara \& Jost-Jakubowska 1978; Ciaciura 1988; Zając 1996; Buliński 2001; Herbichowa \& Herbich 2001; Urbisz 2001; Sobisz et al. 2005; Więcław \& Ciaciura 2005; Szczecińska et al. 2006; Nowak et al.2011; Podgórska 2012; Parusel et al. 2013; Fojcik \& Wierzgoń 2015; Parusel 2016). Especially, the Pomeranian region, with characteristic topographical relief created by the Pleistocene glacial and later denudation processes, is a proper area for mountain plant habitats. There is a crucial role of river valleys that are hardly available for agricultural purposes and partially also for forestry, thus, they contain some remaining fragments of naturally valuable communities with a lot of rare species. It concerns relict species, such as mountain plants in particular (Czubiński 1950). Their occurrence in the river valleys of Pomerania is conditioned by microclimatic factors and high erosion, which makes the conditions similar to lower montane zones (Czubiński 1950; Pawłowska 1972; Herbich 1994, 1998).

Flora of Pomerania, in comparison to other parts of Polish lowlands, stands out with a significant share of mountain species, i.e., plants that have the center of their distribution range in the mountains of Central Europe. In Pomerania, mountain species differ in terms of the time of arrival, origin, migration routes and contemporary ranges of occurrence (Szafer 1930; Czubiński 1950; Markowski \& Chojnacki 1982; Zając 1996).

One of the most precious natural areas of Pomerania, where many representatives of mountain flora occur, is the 'Jar Rzeki Raduni' nature reserve (Wangerin 1919; Urbański 1930; Krawiec \& Urbański 1935; Czubiński 1950; Markowski \& Chojnacki 1982).

The main aim of this research was to define the current state of mountain species in the 'Jar Rzeki Raduni' nature reserve compared to historical data. 


\section{Material and methods}

'Jar rzeki Raduni' is a landscape nature reserve created in 1972, which covers an area of 74,26 ha (Regulation 1972). This reserve protects the Radunia river gorge located on a small outwash plain in the moraine upland of the Kashubian Lake District (Rachocki 1974). The gorge of the Radunia river is $6 \mathrm{~km}$ long and reaches the depth of $40 \mathrm{~m}$, slope inclination often exceeds 40 degrees. Vegetation of the reserve is dominated by oak-hornbeam forests (Herbichowa \& Herbich 1982). Alongside the riverbed, riparian forests and some non-forest communities, such as forb and meadows communities, occur. The Radunia River Valley is also protected as Natura 2000 Special Area of Conservation (Regulation 2007).

In past, the reserve was an object of numerous botanical studies (Schultze 1880; Klinggräff 1885; Urbański 1930; Krawiec \& Urbański 1935; Herbich 1974, 1994, 1998; Herbichowa \& Herbich 1982, 1998; Markowski \& Chojnacki 1982; Piotrowska 1982; Piotrowska \& Stasiak 1982, 1984). A complete floristic list includes 537 species (Piotrowska \& Stasiak 1982). Besides, a high species richness of the studied area is distinguished by a large share of mountain species (Piotrowska \& Stasiak 1984; Herbich \& Markowski 1998).

In 2017, field research was carried out in the whole area of nature reserve. Mountain species were located using Mobile Mapper GPS device. A population of a given species, occurring more than $25 \mathrm{~m}$ away from the other population of this species, was considered a single locality. The localities were next mapped using ArcGIS software.

Scientific names of species follow Mirek et al. 2002. A list of mountain species follows Zając (1996). In case of Dryopteris expansa, mountain affiliation of this species was established after Szczęśniak et al. (2009). Dryopteris expansa was also mentioned by Zając (1996), but due to insufficient data it was not clearly identified as a mountain species. Earlier distribution of mountain species in the study area was determined based on the data from the years 1968-1972 (Piotrowska $\&$ Stasiak 1982). In the mentioned paper, Acer pseudoplatanus was claimed to be a mountain species, thus, it was taken into account in the present study, although currently it is not considered a mountain taxon (Zając 1996).

\section{Results}

Eight mountain species were noted in the area of the “Jar rzeki Raduni' nature reserve.

Aconitum variegatum L. ssp. variegatum Gáy widespread in the study area, 27 localities, mainly at the bottom of valley but also on slopes, in oak-hornbeam forests (Fig. 1).

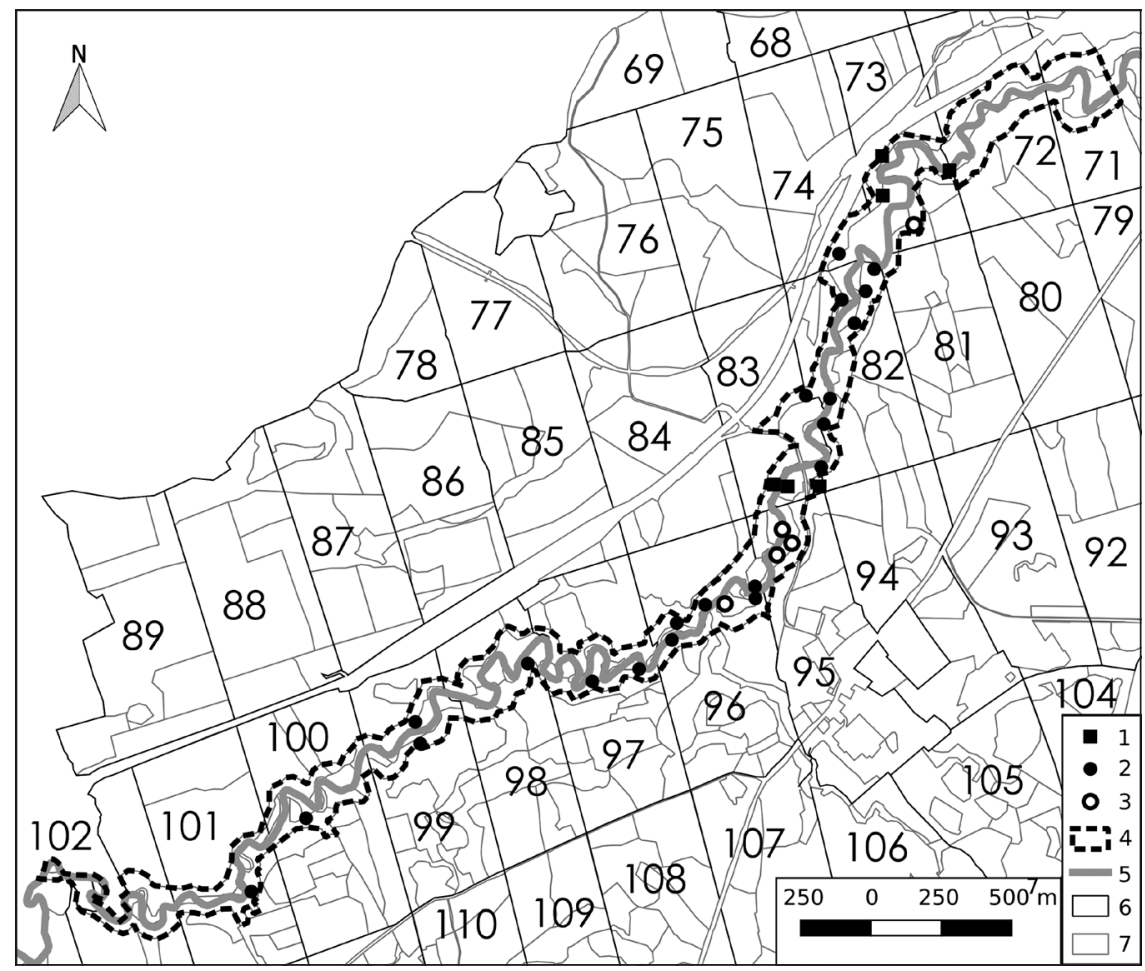

Fig. 1. Distribution of Aconitum variegatum ssp. variegatum in the 'Jar rzeki Raduni' nature reserve Explanations: 1 - new localities, 2 - confirmed localities, 3 - not confirmed localities, 4 - boundary of the reserve, 5 - the Radunia river, 6 - forest divisions, 7 - forest subdivisions 


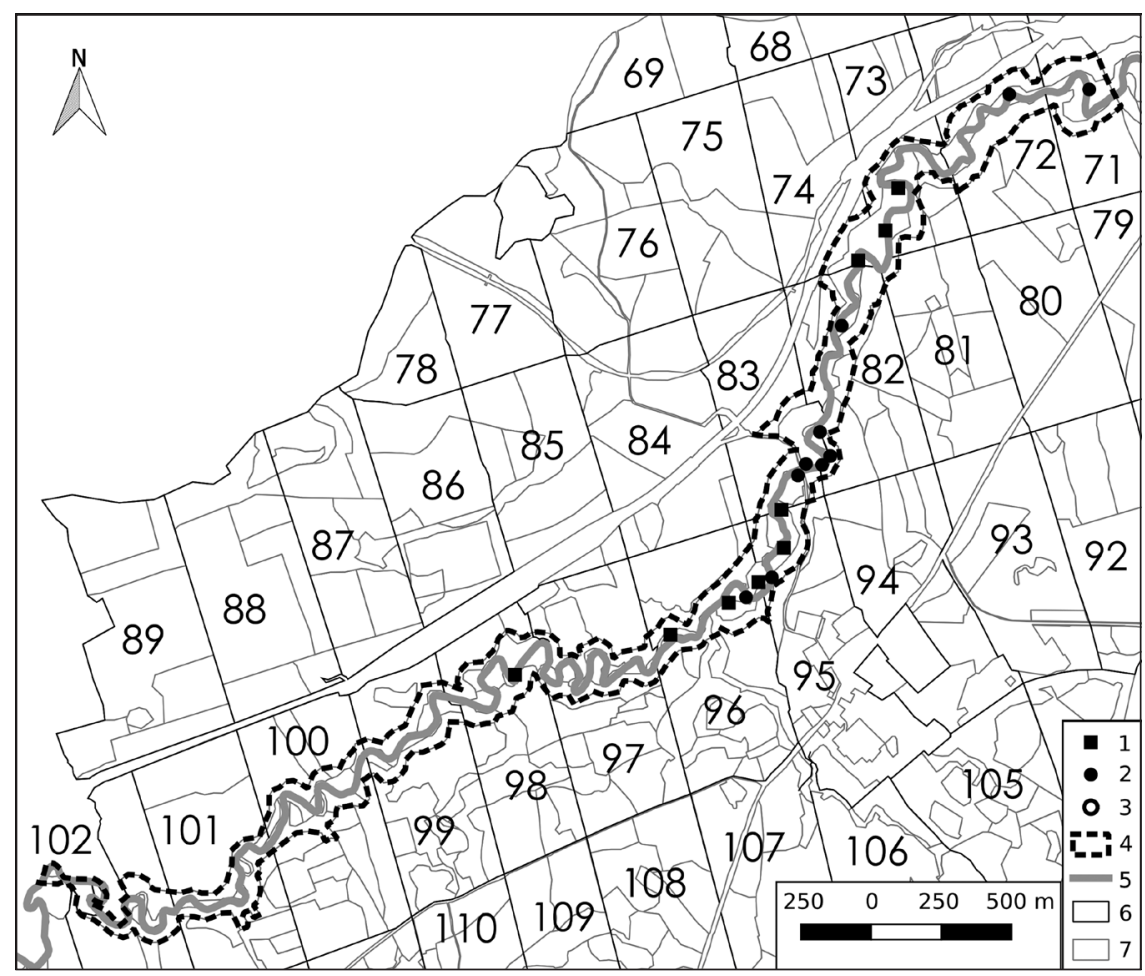

Fig. 2. Distribution of Alnus incana in the 'Jar rzeki Raduni' nature reserve Explanations: see Fig. 1

Alnus incana (L.) Moench - 19 localities, a component of riparian forest stands, also many seedlings (Fig. 2).
Bupleurum longifolium L. -7 localities, less than 100 individuals, on steep slopes, open oak-hornbeam forests (Fig. 3).

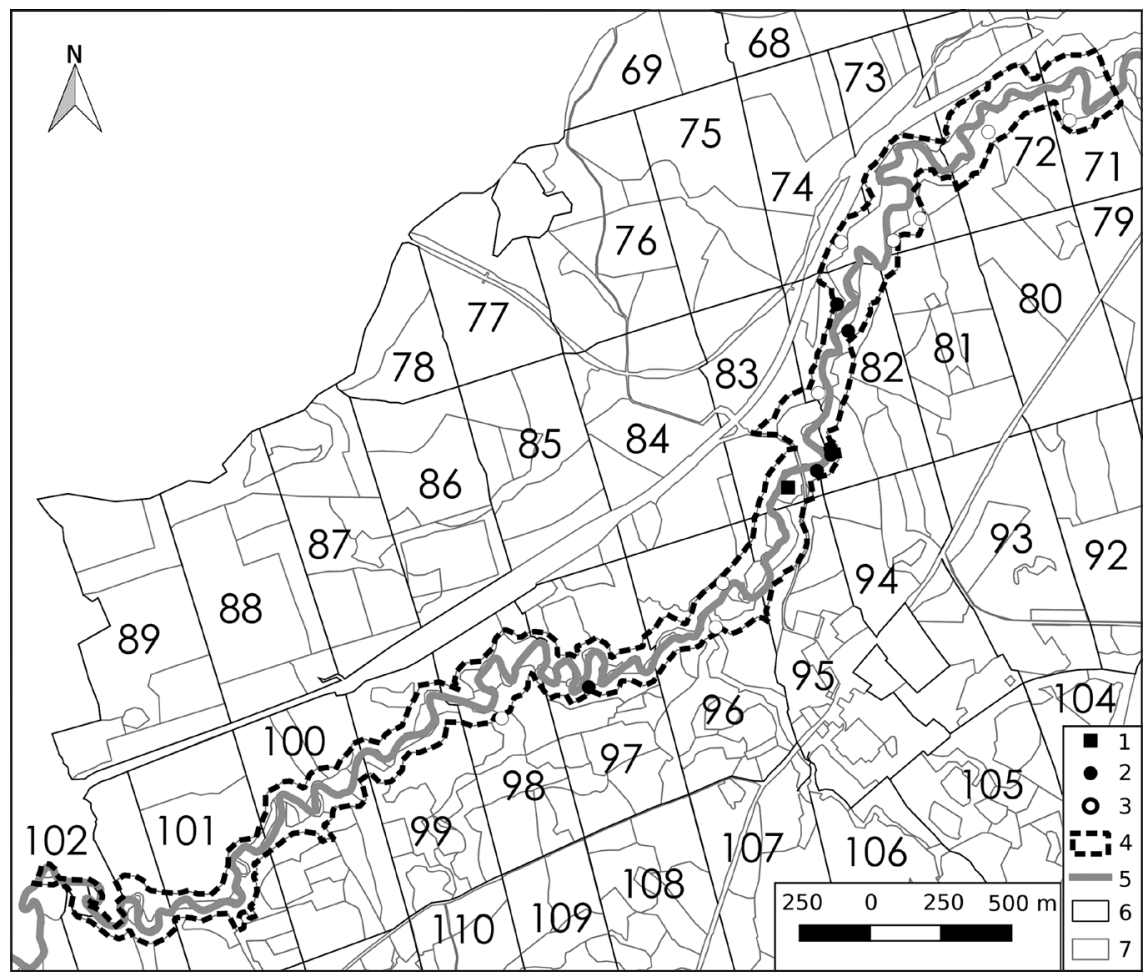

Fig. 3. Distribution of Bupleurum longifolium in the 'Jar rzeki Raduni' nature reserve Explanations: see Fig. 1 


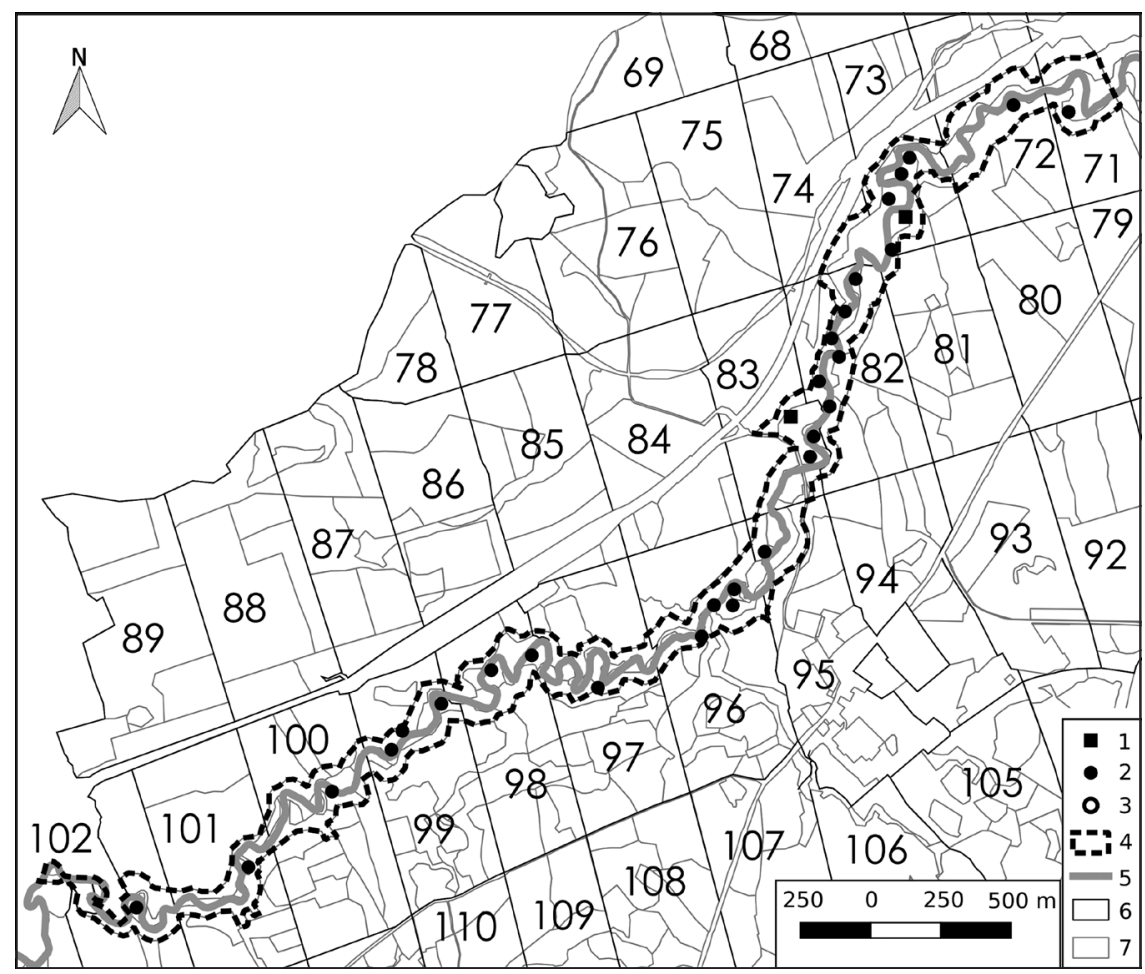

Fig. 4. Distribution of Cherophyllum hirsutum in the 'Jar rzeki Raduni' nature reserve Explanations: see Fig. 1

Chaerophyllum hirsutum L. - 30 localities, at the bottom of the valley, alongside the river, a dominant species of abandoned meadows and some gaps in riparian forest stands (Fig. 4).
Dryopteris expansa (C. Presl) Fraser-Jenk. et Jermy -3 localities, less than 20 specimens, on slopes, in oakhornbeam forests (Fig. 5).

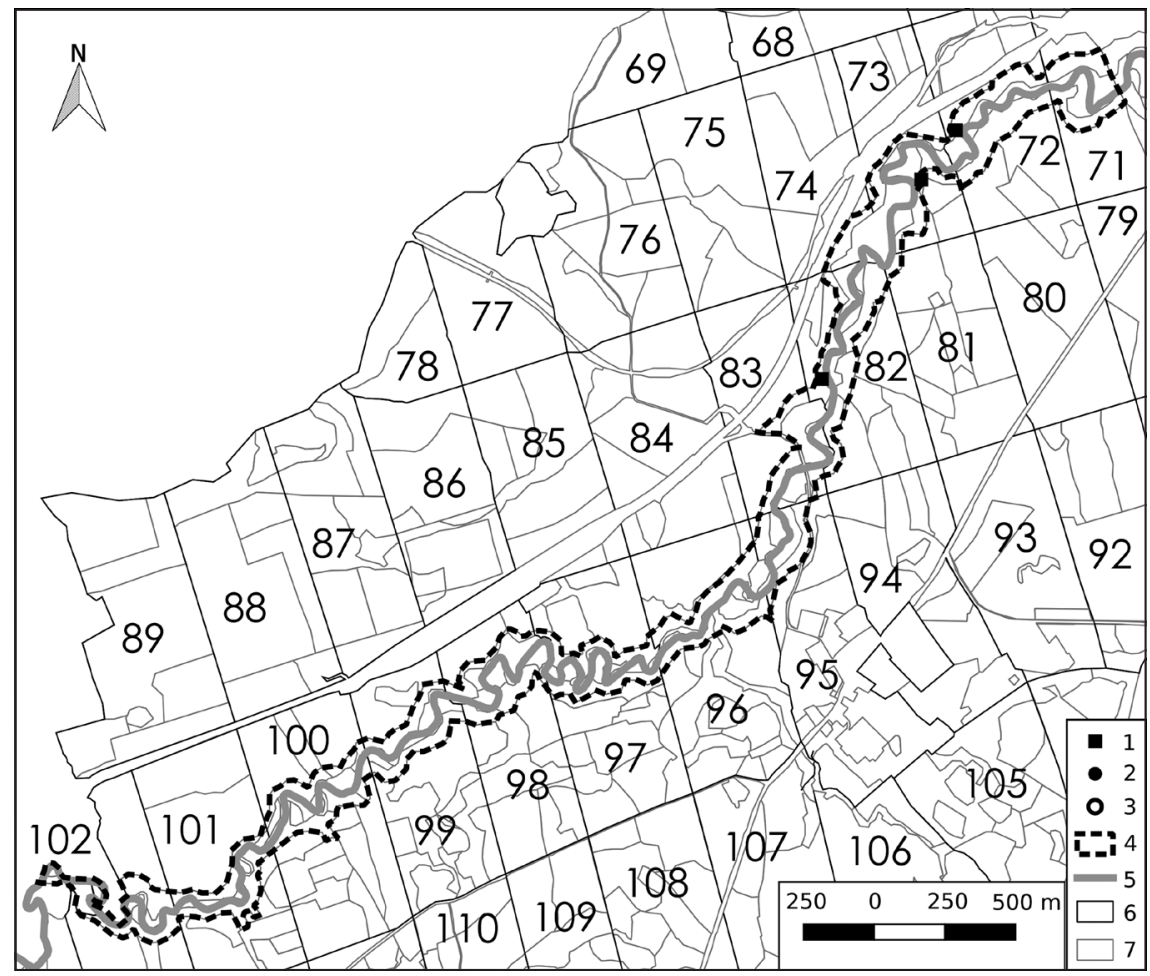

Fig. 5. Distribution of Dryopteris expansa in the 'Jar rzeki Raduni' nature reserve Explanations: see Fig. 1 


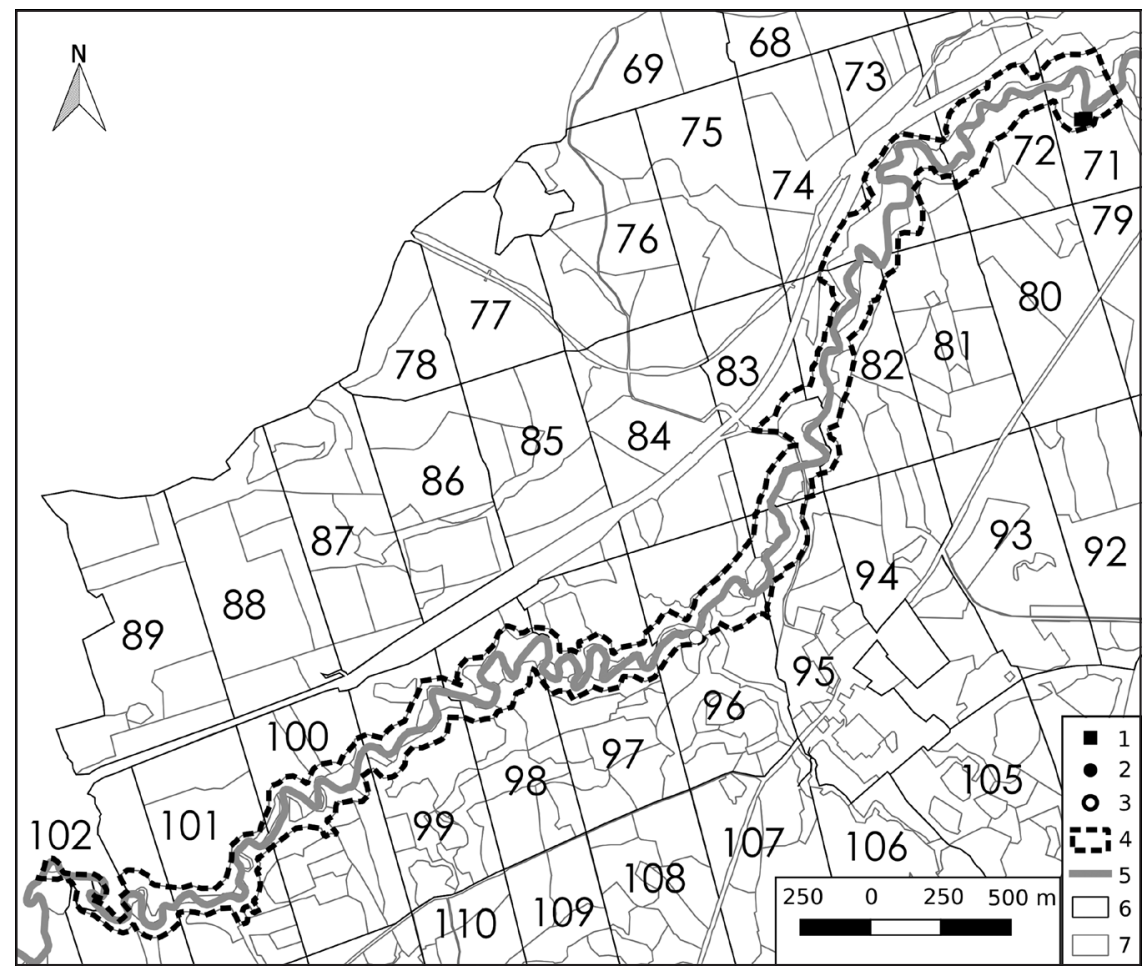

Fig. 6. Distribution of Huperzia selago in the 'Jar rzeki Raduni' nature reserve Explanations: see Fig. 1

Huperzia selago (L.) Bernh. ex Schrank. - only 2 localities in the northern part of the study area, less than 10 specimens, on slopes, in oak-hornbeam forests (Fig. 6).
Pleurospermum austriacum L. - 6 localities, usually plants occur singly, rarely more than 100 individuals in locality, often in vegetative stage, mainly found in the middle part of the study area, on mild slopes and

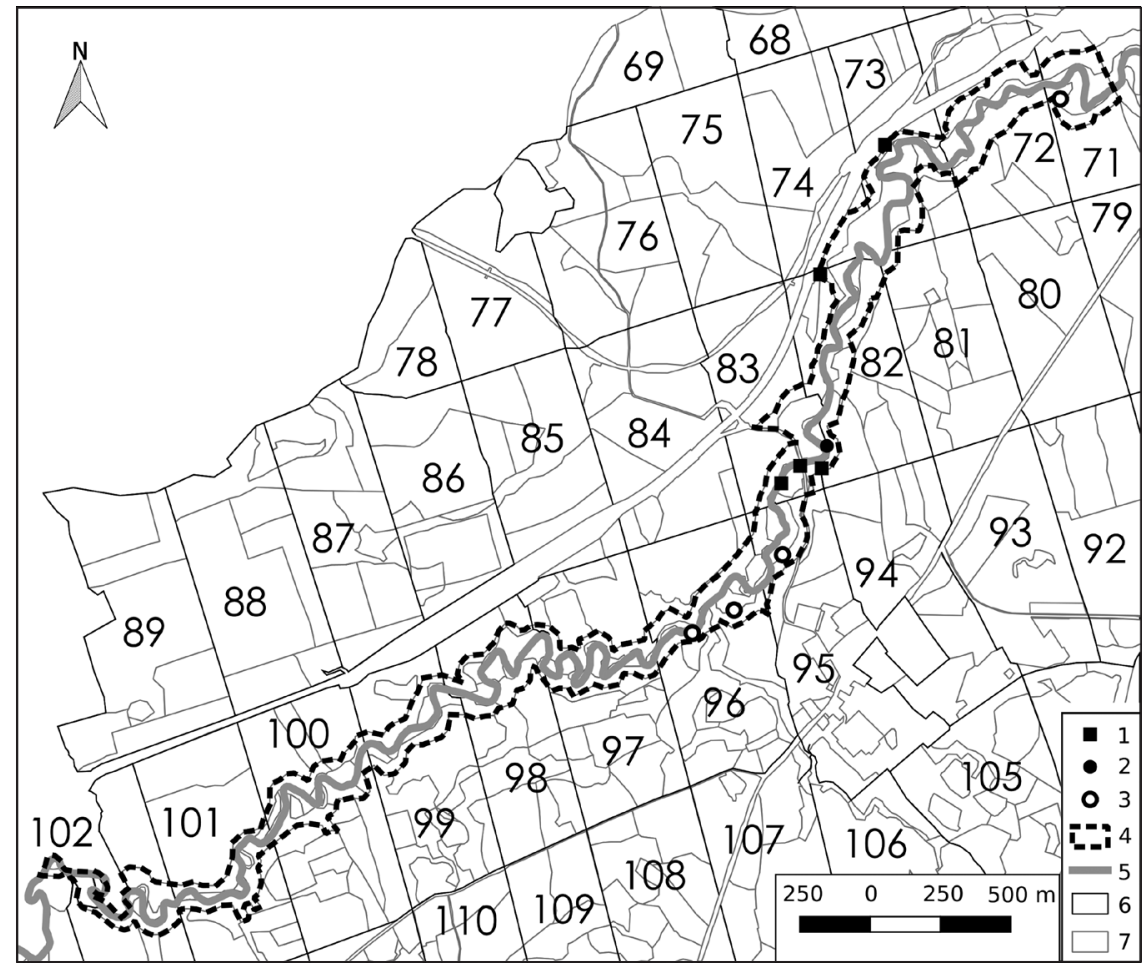

Fig. 7. Distribution of Pleurospermum austriacum in the 'Jar rzeki Raduni' nature reserve Explanations: see Fig. 1 


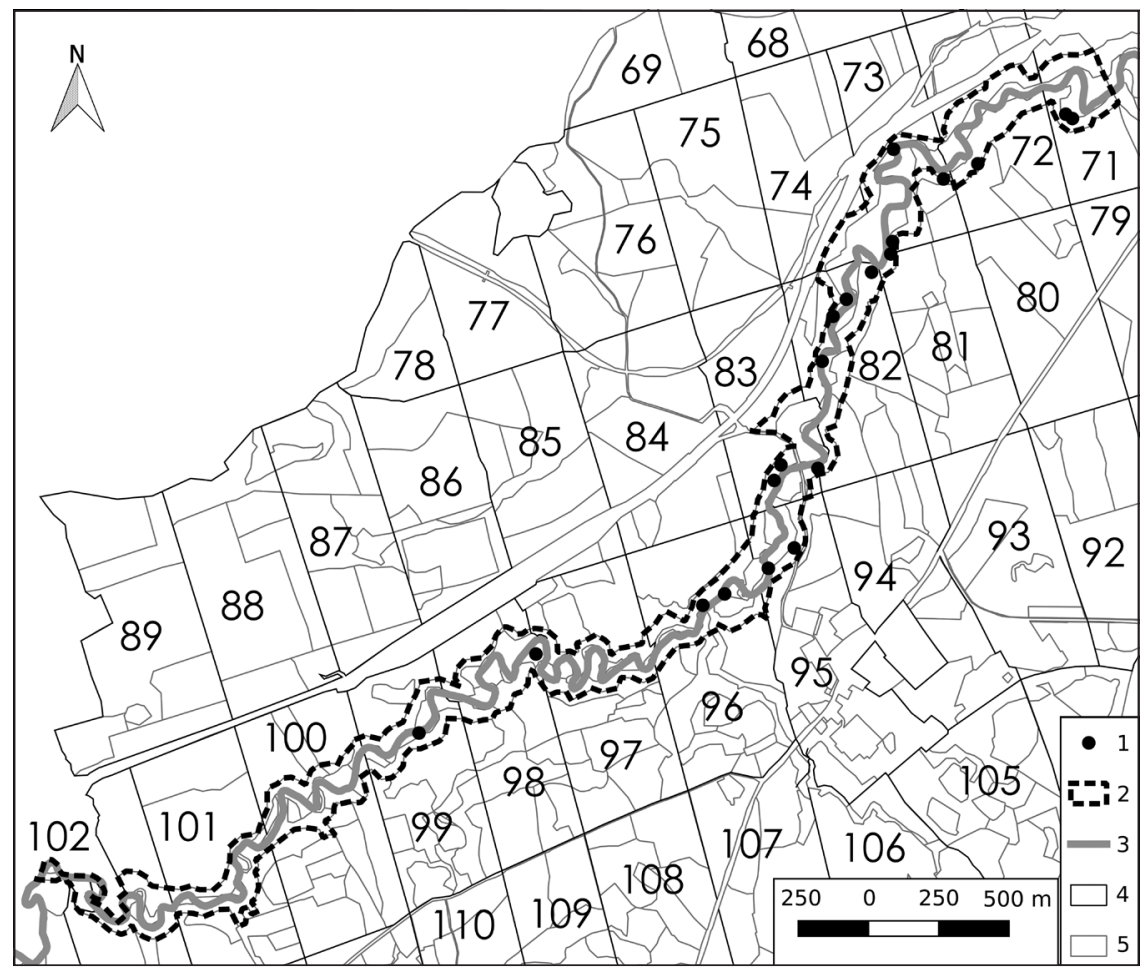

Fig. 8. Distribution of Ribes alpinum in the 'Jar rzeki Raduni' nature reserve

Explanations: 1 - current localities, 2 - boundary of the reserve, 3 - the Radunia river, 4 - forest divisions, 5 - forest subdivisions

at the bottom of the valley, in oak hornbeam forests (Fig. 7).

Ribes alpinum L. -20 localities, mainly on slopes, in oak-hornbeam forests (Fig. 8).
Furthermore, the presence of one species considered to be a mountain species in previous studies was confirmed: Acer pseudoplatanus L. - numerous population ( $>1000$ individuals) in the middle part of the reserve, at

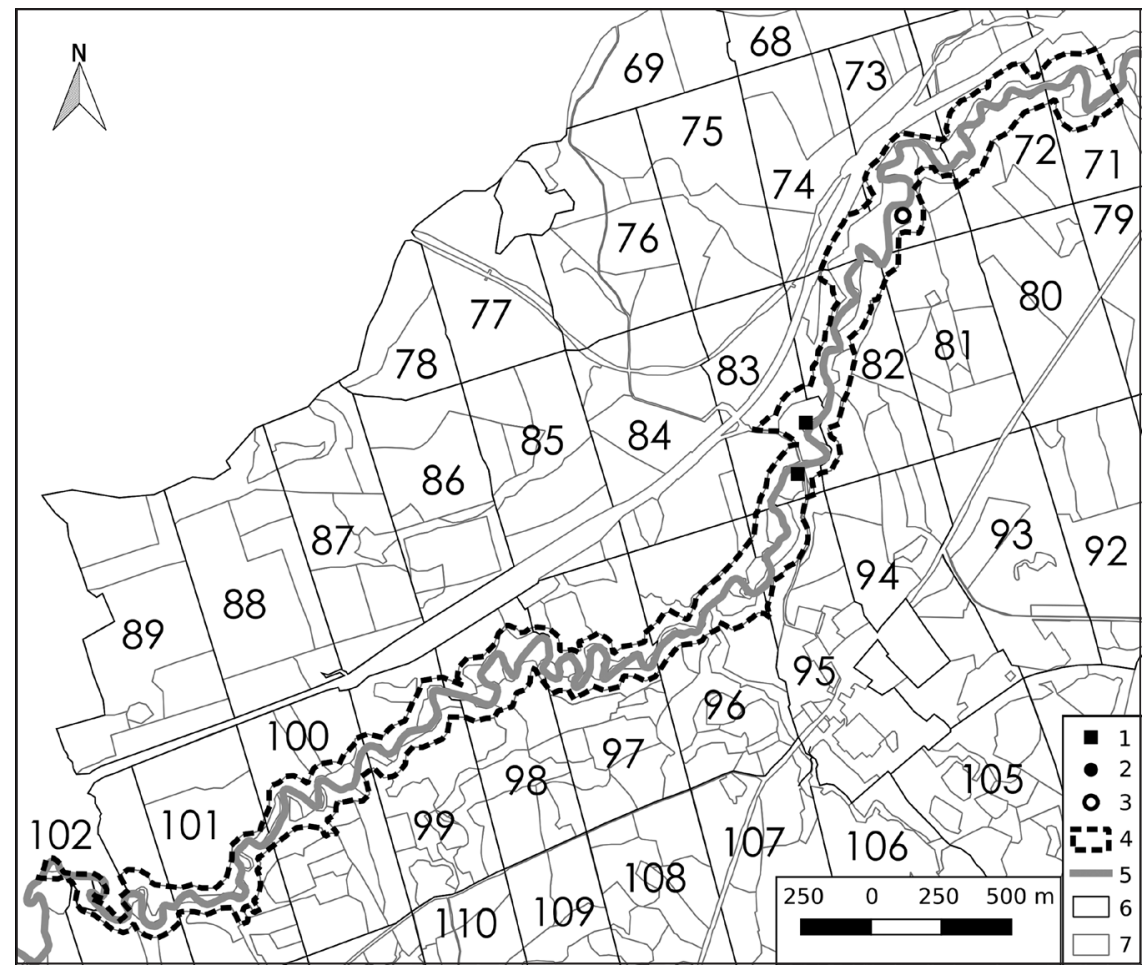

Fig. 9. Distribution of Acer pseudoplatanus in the 'Jar rzeki Raduni' nature reserve. Currently, Acer pseudoplatanus is not considered to be a mountain species (Zajac 1996)

Explanations: see Fig. 1 
the bottom of the valley, 2 localities, forms own community - the regeneration stage of riparian vegetation (Fig. 9).

\section{Discussion}

46 years have passed since the last complex botanical research in the 'Jar rzeki Raduni' nature reserve (Piotrowska \& Stasiak 1982). In terms of global climate change, which impacts on species distribution, especially of mountain species (e.g. Lenoir \& Svenning 2015; Konowalik et al. 2017; Vanneste et al. 2017; Alexander et al. 2018; Czortek et al. 2018), it was hypothesized that this problem concerns also mountain species in Polish lowlands. In fact, our result shows the decline of some mountain species localities, but this concerns only those species that previously formed small populations (Markowski \& Chojnacki 1982; Herbich \& Markowski 1998).

In previous research conducted in the 'Jar rzeki Raduni' nature reserve, 12 mountain species were noted (Schultze 1880; Abromeit 1898-1940; Piotrowska \& Stasiak 1982, 1984). Seven of them were confirmed and one new was found in 2017. This new species for the flora of the reserve (Piotrowska \& Stasiak 1982) is Dryopteris expansa. Species confirmed in the study area were: Aconitum variegatum ssp. variegatum, Alnus incana, Bupleurum longifolium, Chaerophyllum hirsutum, Huperzia selago, Pleurospermum austriacum, and Ribes alpinum (according to Piotrowska \& Stasiak 1982). Also Acer pseudoplatanus, in previous studies claimed to be a mountain species, was confirmed. Currently this species is not considered as a mountain taxon (Zając 1996), thus, the total number of mountain species ever mentioned in the study area is 12 . Also, five species mentioned in old papers and not confirmed in later articles were not found in the present study: Coeloglossum viride (Schultze 1880, not found later), Epipogium aphyllum (Herbich 1974; Piotrowska \& Stasiak 1982, 1984), Melampyrum sylvaticum (Schultze 1880, Abromeit 1898-1940, not found later), Polygonatum verticillatum (Piotrowska \& Stasiak 1982, 1984), and Valeriana sambucifolia (Piotrowska \& Stasiak 1982, 1984).

According to previous data (Piotrowska \& Stasiak 1982), the number of localities of 5 mountain species in- creased. It concerns the following species: Alnus incana, Aconitum variegatum ssp. variegatum, Chaerophyllum hirsutum, Huperzia selago, and Pleurospermum austriacum. Especially, the first of them considerably increased its population in the reserve. The number of localities of Alnus incana increased from 10 to 19, furthermore - all old localities were confirmed. For Chaerophyllum hirsutum and Huperzia selago, 2 new localities were found. Six new localities of Aconitum variegatum ssp. variegatum were found, but 5 were not confirmed. In case of Pleurospermum austriacum, 5 new localities were found, 2 were confirmed and 4 were not found. The previous number of localities of Ribes alpinum in the reserve is unknown, but it was noted as common (Piotrowska \& Stasiak 1982).

There is only one species with the decreased number of localities (according to Piotrowska \& Stasiak 1984): Bupleurum longifolium (6 out of 15 were confirmed, one new).

Species not confirmed (Melampyrum sylvaticum, Coeloglossum viride, Epipogium aphyllum, Polygonatum verticillatum, and Valeriana sambucifolia) occurred in the study area as relicts, and the reasons of their withdrawal are unclear. This could be caused by the climate change in recent years, but it is definitely related to dynamic geomorphological processes in the river valley, and changes in land use. Taking into account that their populations probably were residual, it is not expected that these species would return. The exception is Epipogium aphyllum that, given its ecology, is hard to observe in field (Taylor \& Roberts 2011). The localities are not in danger of direct human activity, because the terrain is nearly inaccessible for tourists, the former tourist trail is damaged and not repaired. The danger for some localities could result from the process of natural secondary succession, started when the area was taken under protection. Also the impact of alien species is indiscernible, thus, the communities in the studied nature reserve are very well preserved.

Acknowledgements. We are thankful to Regional Directorate for Environmental Protection in Gdańsk for permission to carrying out the research in the nature reserve (Decission number: RDOŚ-Gd_WOC.6205.32.2018.MJ.1). We are also grateful for the precious advices of anonymous reviewers, that were crucial for the final shape of the paper. 


\section{References}

Aвromeit J. 1898-1940. Flora von Ost- und Westpreussen. I-V.1248 pp. Berlin, Königsberg Pr.

Alexander J. M., Chalmandrier L., Lenoir J., Burgess T. I., Essl F., Haider S., Kueffer C., McDougall K., Milbau A., Nunez M. A., Pauchard A., Rabitsch W., Rew L. J., SAnders N. J. \& Pellissier L.2018. Lags in the response of mountain plant communities to climate change. Global Change Biology 24(2): 563-579. DOI: 10.1111/gcb.13976

BulıŃski M. 2001. Nowe stanowiska Poa chaixii Vill. na Pomorzu Gdańskim. Acta Botanica Cassubica 2: 83-87.

Ciaciura M. 1988. Charakterystyka rozmieszczenia górskich gatunków naczyniowych na Śląsku. Rozprawy Habilitacyjne Akademii Medycznej we Wrocławiu 12(1): 1-157, (2): 1-204.

Czortek P., Eycott A. E., Grytnes J. A., Delimat A., Kapfer J. \& JARoszewicz B. 2018. Effects of grazing abandonment and climate change on mountain summits flora: a case study in the Tatra Mts. Plant Ecology 3: 261-276. DOI: 10.1007/s11258-018-0794-6

Czubiński Z. 1950. Zagadnienia geobotaniczne Pomorza. Bad. Fizjogr. Pol. Zach. 2(4): 439-658.

FoJCIK B. \& WieRzGOŃ M. 2015. Lowland station of the Gentiana asclepiadea L. in Mikołów (Silesian Upland, S Poland). Steciana 19(1): 9-12. DOI: 10.12657/ steciana.019.002

Herbich J. 1974. A new locality of Epipogium aphyllum (Schm.) Sw. in the Casubian Lake region. Fragm. Flor. Geobot. 20(3): 303-305 (in Polish).

Herbich J. 1994. Spatial and dynamical diversity of the vegetation in valleys in a young-glacial landscape exemplified by the Kashubian Lakeland (northern Poland). Monographiae Botanicae 76: 1-209 (in Polish). DOI: https://doi.org/10.5586/mb.1994.001

Herbich J. 1998. Jar Raduni. Geneza przełomu, związek roślinności z wiekiem stoków. In: J. HerBich \& M. Herbichowa (eds.). 1998. Szata roślinna Pomorza - zróżnicowanie, dynamika, zagrożenia, ochrona. Przewodnik Sesji Terenowych 51. Zjazdu PTB 15-19 IX 1998, pp. 163-164, Uniwersytet Gdański, Gdańsk.

Herbichowa M. \& Herbich J. 1982. Naturalne zbiorowiska leśne rezerwatu Jar rzeki Raduni. Ochrona Przyrody 44: 52-64.

Herbich J. \& Herbichowa M. 1998. Jar Raduni. Naturalne zbiorowiska leśne. In: J. Herbich \& M. Herbichowa (eds.). Szata roślinna Pomorza - zróżnicowanie, dynamika, zagrożenia, ochrona. Przewodnik Sesji Terenowych 51. Zjazdu PTB 15-19 IX 1998, pp. 171177, Uniwersytet Gdański, Gdańsk.

Herbichowa M. \& Herbich J. 2001. Nowe stanowisko Petasites albus (L.) Gaertn. na Niżu Polskim. Acta Botanica Cassubica 2: 93-95.

Herbich J. \& MARKOwSKi R. 1998. Flora roślin naczyniowych ze szczególnym uwzględnieniem gatunków górskich. In: J. Herbich \& M. Herbichowa (eds.). Szata roślinna
Pomorza - zróżnicowanie, dynamika, zagrożenia, ochrona. Przewodnik Sesji Terenowych 51. Zjazdu PTB 15-19 IX 1998, pp. 167-171, Uniwersytet Gdański, Gdańsk (in Polish).

JaKubowska-Gabara J. \& Jost-JaKuBowska B. 1978. Element górski we florze Polski środkowej. Fragm. Flor. Geobot. 24: 259-272.

KLINGGRÄFF H. 1885. Botanische Reisen im Karthaus in den Monten Juni, Juli und August 1884. Ber. Westpr. Bot.Zool. Ver. 8:64-84.

Konowalik K., Proćków M. \& Proćków J. 2017. Climatic niche of Selinum alatum (Apiaceae, Selineae), a new invasive plant species in Central Europe and its alterations according to the climate change scenarios: Are the European mountains threatened by invasion? PloS one 12(8), e0182793. DOI: 10.1371/journal. pone. 0182793

KRAWIEC F. J. \& URBAŃSKi J. 1935. Mapa pomników i zabytków przyrody powiatu Kartuskiego. 28 pp. Państwowa Rada Ochrony Przyrody, Poznań.

Lenoir J. \& Svenning J. C. 2015. Climate-related range shifts-a global multidimensional synthesis and new research directions. Ecography 38(1): 15-28. DOI: 10.1111/ecog.00967

Markowski R. \& Chojnacki W. 1982. Rośliny górskie w rezerwacie Jar rzeki Raduni. Ochrona Przyrody 44: 43-51.

Mirek Z., Piękoś-Mirkowa H., Zając A. \& Zając M. 2002. Flowering plants and pteridophytes of Poland. A checklist. In: Z. MireK (ed.). Biodiversity of Poland, 1, 442 pp. W. Szafer Institute of Botany, Polish Academy of Sciences, Kraków.

Nowak T., Urbisz A., Kapusta P. \& Tokarska-Guzik B. 2011. Distribution patterns and habitat preferences of mountain vascular plant species in the Silesian Uplands (southern Poland). Polish Journal of Ecology 59(2): 219-234.

Parusel J. B., Baczkiewicz A. \& Buczkowska K. 2013. Genetic diversity of the Streptopus amplexifolius (L.) DC. populations from the Polish Western Carpathians. Acta Biologica Cracoviensia, Seria Botanica 55, Supplement 1: 62 .

PARUSEl J. B. 2016. „Nowe” gatunki górskie ze Śląska na niżu Polski. Fragm. Flor. Geobot. Polonica 23(2): 273-288.

PawŁowska S. 1972. Charakterystyka statystyczna i elementy flory polskiej. In: W. SZAFER \& K. ZARZYCKI (eds.). Szata roślina Polski, vol. I, pp. 129-206. PWN, Warszawa.

PiotrowsKa H. 1982. Ogólna charakterystyka warunków siedliskowych rezerwatu Jar Rzeki Raduni na Pojezierzu Kaszubskim. Ochrona Przyrody 44: 22-27.

Piotrowska H. \& Stasiak J. 1982. Flora rezerwatu Jar Rzeki Raduni na Pojezierzu Kaszubskim. Ochrona Przyrody 44: $28-42$.

Piotrowska H. \& Stasiak J. 1984. Rośliny naczyniowe rezerwatu 'Jar rzeki Raduni' na Pojezierzu Kaszubskim. 
Zeszyty Naukowe Wydziału Biologii i Nauk o Ziemi Uniwersytetu Gdańskiego 5: 94-124.

PodgóRSKA M. 2012. Zagadnienia geobotaniczne Garbu Gielniowskiego. Część I. Elementy kierunkowe i gatunki górskie. Fragm. Flor. Geobot. Polonica 19(2): 485-497.

RACHOCKI A. 1974. Przebieg i natężenie współczesnych procesów rzecznych w korycie Raduni. Dokumentacja Geograficzna 4: 1-120.

Regulation 1972. Zarządzenie Ministra Leśnictwa i Przemysłu Drzewnego z dnia 23 czerwca 1972 roku w sprawie uznania za rezerwaty przyrody. MP 36, poz. 202.

Regulation 2007. Commission Decision of 13 November 2007 adopting, pursuant to Council Directive 92/43/ EEC, a first updated list of sites of Community importance for the Continental biogeographical region (notified under document number C(2007) 5403). Official Journal of the European Union L12, 649 pp.

Schultze S. 1880. Bericht über die im Jahre 1879 im Juni, August und September und im Jahre 1880 im Juni im Kreis Karthaus fortgesetzte botanische Excursion. Ber. Westpr. Bot.-Zool. Ver. 3: 56-67.

Sobisz Z., Truchan M. \& Kazimierski J. 2005. Fitocenozy ze skrzypem olbrzymim (Equisetum telmateia Ehrh.) wybranych biotopów w Parku Krajobrazowym ,Dolina Słupi” (Pomorze Zachodnie). Słupskie Prace Biologiczne 2: 115-121.

SZAFER W. 1930. Element górski we florze niżu polskiego. Rozpr. Wydz. Mat.-Przyr. Ser. 3 Dział B. 69: 83-196.

Szczecińska M., HoŁdyński C. \& Sawicki J. 2006. Genetic diversity of lowland and mountain population of Polygonatum verticillatum (L.) All. determinated on the basis of isozymatic analysis. Biodiv. Res. Conserv. 3-4: $240-244$.
SzczęŚniak E., Tląka D. \& Rostański A. 2009. Key to identification and descriptions of species of Bucklerferns (Dryopteris Adans.) occurring in Poland. In: E. Szczęśsinak \& E. Gola (eds.). Genus Dryopteris Adans. in Poland, pp. 5-34. Polish Botanical Society \& Institute of Plant Biology, University of Wrocław, Wrocław.

TAYlor L. \& RoberTs D. L. 2011. Biological Flora of the British Isles: Epipogium aphyllum Sw. Journal of Ecology 99(3): 878-890. DOI: 10.1111/j.13652745.2011.01839.x

URBAŃSKI J. 1930. Wycieczka w dolinę Raduni (projekt rezerwatu pod Babim Dołem). Wyd. Okr. Kom. Ochr. Przyr. na Wlkp. i Pom. w Poznaniu 2: 25-32.

Urbisz A. 2001. Gatunki górskie we florze naczyniowej Płaskowyżu Rybnickiego (Wyżyna Śląska). Fragm. Flor. Geobot. Polonica 8: 63-70.

Vanneste T., Michelsen O., Graae B. J., Kyrkjeeide M. O., Holien H., Hassel K., Lindmo S., Kapás R. E. \& De Frenne P. 2017. Impact of climate change on alpine vegetation of mountain summits in Norway. Ecological Research 32(4): 579-593. DOI: 10.1007/ s11284-017-1472-1

WANGERIN W. 1919. Die montane Elemente in der Flora des nordostdeutschen Flaschlandes. Schrift. Naturf. Ges. Danzig N. F. 15(1): 13-85

WiĘCŁaW H. \& Ciaciura M. 2005. Gatunki górskie we florze roślin naczyniowych Ińskiego Parku Krajobrazowego (Pojezierze Ińskie). Fragm. Flor. Geobot. Polonica 12(1): 57-66.

ZAJĄC M. 1996. Mountain vascular plants in the Polish lowlands. Pol. Bot. Stud. 11: 1-92. 